\title{
RESEARCH NOTE \\ Removal of the epi- and mesocarp from the semi-mature fruit of Peumus boldus and not the use of gibberellic acid promotes the highest seed germination
}

\author{
Rómulo Santelices-Moya ${ }^{1}$, Antonio Cabrera-Ariza ${ }^{1,2}$, Fernando Ávila-Rojas ${ }^{1}$, \\ and Patricia Silva-Flores ${ }^{1,2}$ \\ 'Universidad Católica del Maule, Facultad de Ciencias Agrarias y Forestales, Centro del Secano, Avenida \\ San Miguel 3605, Talca, Chile. \\ ${ }^{2}$ Universidad Católica del Maule, Vicerrectoría de Investigación y Postgrado - Centro de Investigación de \\ Estudios Avanzados del Maule (CIEAM). Avenida San Miguel 3605, Talca, Chile.
}

\begin{abstract}
R. Santelices-Moya, A. Cabrera-Ariza, F. Ávila-Rojas, and P. Silva-Flores. 2020. Removal of the epi- and mesocarp from the semi-mature fruit of Peumus boldus and not the use of gibberellic acid promotes the highest seed germination. Int. J. Agric. Nat. Resour. 145-151. Because of climate change, wildfire events have increased in the semi-arid ecosystems of the world. In this context, it is necessary to count with efficient tools for the rehabilitation or restoration of those systems. Plant propagation is crucial to obtain plants for rehabilitation programs, and it becomes a limiting factor in the success of those initiatives. For this, it is necessary to know how relevant factors affect seed germination in plants of interest. Peumus boldus is a dominant plant species of the Mediterranean area of Chile that has been severely affected by wildfire events. Consequently, in this investigation, the joint effect of pregermination treatments such as epicarp and mesocarp removal with the use of gibberellic acid on the germination of semimature fruits of $P$. boldus was studied. The results show that only the removal of the epicarp and the mesocarp had a significant effect on seed germination, reaching a proportion of $51.4 \%$, which is the highest value reported so far in a published study with a controlled setting for $P$. boldus. Therefore, to obtain a high proportion of $P$. boldus plantlets for use in rehabilitation programs; seeds should be collected in December and exposed to the pre-germination treatment of pericarp and mesocarp removal without using gibberellic acid in doses lower than or equal to $10 \mathrm{~g} \mathrm{~L}^{-1}$.
\end{abstract}

Key words: AIB, boldo, endocarp, mesocarp, pericarp, pre-germination treatment.

\section{Introduction}

Wildfire events are one of the most extended ecological disturbances in natural ecosystems. They affect a variety of temporal and spatial scales

Received Oct 25, 2019. Accepted Jul 20, 2020.

Corresponding author: psilva@ucm.cl the dynamic of the vegetation layer because of their removal (Lhermitte et al., 2011). Although wildfire events have been a modeling agent of the Chilean landscape, especially in semi-arid ecosystems, currently and as in several parts of the world, the fire regimes have increased at an alarming pace (Úbeda \& Sarricolea, 2016). The greatest wildfire event ever registered for the 
Chilean semi-arid zone, or Mediterranean area, occurred during the 2016-2017 summer season (de la Barrera et al., 2018). One of the events destroyed, in just three weeks, 184.000 ha of agricultural and natural forest systems as well as plantations (Valencia et al., 2018). One of the most affected forest systems was the sclerophyllous matorral and forest, where Peumus boldus Molina (boldo), an endemic species of Central Chile (Donoso et al., 2015), dominates in several plant formations (Gajardo, 1994; Luebert \& Pliscoff, 2006).

The wildfire event patterns, frequency, and intensity have increased at a worrying rate in Chile (Úbeda \& Sarricolea, 2016), and together with the increment of drought periods and high temperatures, the possibility of future disturbances for $P$. boldus is likely. In this context, effective tools helping to cope with the effects of wildfire events in ecosystems are urgently needed. Ecosystem restoration or rehabilitation in forestry terms consists in introducing key components as plants into an ecosystem to recover eventually as its original state (Vallejo et al., 2003). In this sense, the germination of most of the seeds produced by a plant is crucial to use it in rehabilitation programs, becoming a limiting factor in the success of those initiatives. P. boldus, like many other plant species, has difficulty in terms of seed germination since their seeds have a dormancy mechanism that inhibits germination even though the environmental conditions seem suitable (Baskin \& Baskin, 2014). In plant cultivation practice, the dormancy must be overcome to reach homogeneous germination and, in consequence, to produce plants that are functionally suitable to be established in the field.

It has been proposed that $P$. boldus has a dormancy mechanism that allows it to manage unfavorable conditions during the dissemination season (Figueroa et al., 1996). In this context, published investigations have shown the effects of different strategies to break dormancy, reaching germination percentages between 0 and $69.6 \%$. Homann (1969) reported 19\% germination after one year of sowing seeds stored at $3{ }^{\circ} \mathrm{C}$ for three weeks and having eliminated the epicarp and mesocarp. These two layers have been reported to act as an inhibitor of germination due to the presence of essential oils such as terpineol and eugenol (Rodríguez et al., 1983). Other experiments where seeds were exposed to different temperatures for different lengths of time $\left(20^{\circ} \mathrm{C}\right.$ for 16 hours vs. $30^{\circ} \mathrm{C}$ for 8 hours) to break down dormancy over 30 days did not result in the germination of seeds (Donoso \& Cabello, 1978). Interestingly, Cabello and Donoso (2013) pointed out that the month of the year for seed recollection is an important factor. They collected seeds in December (early maturation) and reached a $44 \%$ germination rate after 3.5 months of sowing. In the same line, García and González (2018) reported several values for the germination capacity of seeds from different origins collected between December and January. Those values are in a range between $2.4 \%$ and $69.6 \%$, reaching the highest value in a condition of seeds with pulp collected in January. However, the authors do not explain the experimental setting or statistical analysis, thus it is not possible to know whether this was an exception or a normal phenomenon. Finally, Vogel et al., (2005) reported that the use of gibberellic acid in doses of $10 \mathrm{~g} \mathrm{~L}^{-1}$ for 48 hours produced a germination rate of $34 \%$ for seeds six months after sowing them. Thus, the published evidence shows that using seeds collected in early maturation (December-January), together with the removal of epicarp and mesocarp, as well as the use of gibberellic acid, would be three important factors involved in the germination success of $P$. boldus. However, so far, the joint use of these factors has not been explored to possibly reach a higher proportion of germinated seeds. Accordingly, this study aims to evaluate the joint effect of two pre-germination treatments, specifically the removal of epi- and mesocarp and the uses of gibberellic acid in the process of germination of $P$. boldus seeds collected in December. It was expected that the application of both pre-germination treatments into one set of seeds would allow a higher germination rate of seeds due to their cumulative effect, relative 
to the use of the two pre-germination treatments separately.

\section{Materials and Methods}

The experiment was conducted in a nursery of the Universidad Católica del Maule in the city of Talca, Maule region. Seeds were collected at the end of December in a typical area of a semi-arid environment ( $35^{\circ} 35^{\prime} \mathrm{S}, 72^{\circ} 57^{\prime} \mathrm{W}, 225 \mathrm{~m}$. a. s. 1.) from a forest on a shady slope. After harvest, the fruits were stored at $4^{\circ} \mathrm{C}$ for five days, and afterward, the sowing was performed in wooden seed pots $(40 \times 40 \mathrm{~cm})$ Using sterilized river sand as a substrate. According to the treatments, the epicarp and mesocarp were removed in some fruits (soaking them in distilled water) and others were soaked in gibberellic acid ( $\left.\mathrm{GA}_{3}\right)$ for 24 hours. Treatments were watered manually daily to have the substrate at the seed level always at field capacity. The experiment lasted eight months, and the experimental design consisted of a randomized block design with a factorial arrangement. Accordingly, the experiment had six treatments, with three replicates by treatment (18 experimental units in total). Each experimental unit had 50 seeds of $P$. boldus (Table 1).

The response variables evaluated were the germinative capacity (percentage of seeds respective total number of sowed seeds) and the maximum value of Czabator (maximum quotient between the cumulative percentage of germination at day x, divided by x (Czabator, 1962)). Additionally, the germinative energy was determined (percentage of cumulative germination at the day that the

Table 1. Experimental design with a factorial arrangement. Two factors were considered: Gibberellic acid with three levels and Epi- and mesocarp with two levels. Accordingly, the experiment had six treatments. Every treatment had 3 replicates with 50 seeds in each replicate.

\begin{tabular}{|c|c|c|c|}
\hline & & \multicolumn{2}{|c|}{ Epi- and mesocarp (A) } \\
\hline & & With $(+) \mathrm{A}$ & Without (-) A \\
\hline \multirow{3}{*}{ Gibberellic acid } & $0 \mathrm{~g} \mathrm{~L}^{-1}$ & $0 \mathrm{~A}+$ & 0A- \\
\hline & $5 \mathrm{~g} \mathrm{~L}^{-1}$ & $5 \mathrm{~A}+$ & $5 \mathrm{~A}-$ \\
\hline & $10 \mathrm{~g} \mathrm{~L}^{-}$ & $10 \mathrm{~A}+$ & $10 \mathrm{~A}-$ \\
\hline
\end{tabular}

maximum value is reached), and the period of germination (number of days where the maximum value is reached).

To analyze the importance of each factor ("Epiand Mesocarp" and "Gibberellic acid") and the interaction of both on germinative capacity, a generalized linear model (GLM) with a quasibinomial distribution was used (Fatoretto et al., 2018). Statistical analyses were performed using the R software version 3.5.1 (R Core Team, 2019) as well as the graphs by using the 'ggplot' (Wickham, 2016) package in the RStudio environment (version 1.1.383).

\section{Results and Discussion}

Contrary to expectations, there was no cumulative effect of using two pre-germination treatments on the germination of seeds collected in December, since the interaction between the factors studied was not significant $(\mathrm{F}=0.9095$; $\mathrm{p}=0.3564$ ). Importantly, only the removal of the epicarp and mesocarp from the fruits of $P$. bol$d u s$ had a significant effect on seed germination $(\mathrm{F}=52.6671 ; \mathrm{p}<0.001)($ Table 2 and Figure 1). This is in accordance with Homann (1969), although that study reached a much lower percentage (19\% vs. $51.4 \%$ here). Our results suggest that it is likely that the germination difficulty was not related to the complete pericarp since here only the epicarp and mesocarp were removed and a $51.4 \%$ germination rate was reached. It could be possible that most of the germination inhibitors were located only in those two layers of the fruit and not in the complete pericarp. In fact, at the beginning of the process of fruit maturation (i.e., December), the endocarp is already completely lignified and hard (Botti \& Cabello, 1990). In the current study, the germination occurred with fruits harvested in December, and only the epicarp and mesocarp were removed. Thus, it could be that the endocarp does not constitute a barrier for germination as suggested by Botti and Cabello (1990), and hence the difficulty might 
be located mainly in the outer layers. However, further studies are needed to confirm this idea. It is important also to highlight that the removal of the epicarp and mesocarp for this study allowed reaching a mean germination percentage of $51.4 \%$, which is among the highest values reported so far in a published study in a controlled setting for $P$. boldus. In contrast with the results of this study, García and González (2018) reported a maximum value of $69.6 \%$ of germination with seeds collected in January and without removal of the pulp. However, since the experimental design was not clearly stated, it is impossible to accurately discriminate the factor that influenced their results. Despite this, it is interesting that they reached a higher value than here, and their results should be considered for further study in an experimental setting with seeds collected in December and January (month as a factor) from the same location. The results of the present study allow us to remark as well on the importance of also considering the pulp factor.

In contrast to the removal of epicarp and mesocarp treatment effects, the gibberellic acid dose applied in this study did not significantly affect seed germination $(\mathrm{F}=0.0145 ; \mathrm{p}=0.9058)$ (Table 2 and Figure 1). Although gibberellic acid is a germination promoter (Baskin \& Baskin, 2014), when is applied exogenously in doses at least up to $10 \mathrm{~g} \mathrm{~L}^{-1}$, it did not have a significant effect on the germinative capacity of $P$. boldus seeds, as is shown in the present study. Gibberellic acid directly affects seed germination and is in a relatively high amount in developmental seeds; however, the concentration is reduced in those mature seeds with dormancy, as in P. boldus. The concentration of abscisic acid increases during the fruit maturation process (Hartmann \& Kester, 1999). Thus, for $P$. boldus, it is possible that during this process the proportion between promoters and inhibitors of germination changes. Due to this, a deeper dormancy might be generated in

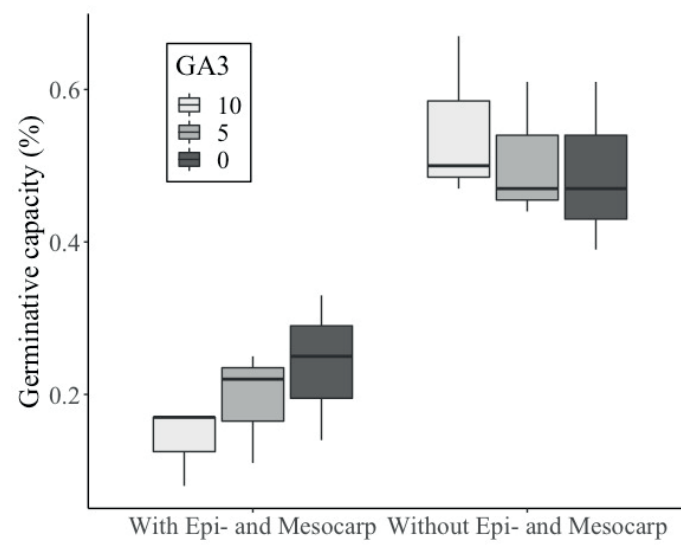

Figure 1. Boxplot showing the effect of the presence/ absence of epicarp and mesocarp and the use of three doses of gibberellic acid $\left(\mathrm{GA}_{3}\right.$ in $\left.\mathrm{g} \mathrm{L}^{-1}\right)$ upon the germination percentage of the seeds of Peumus boldus after eight months of experiment. A significant difference occurs only between both levels of Epi- and Mesocarp factor $(\mathrm{P}<0.05)$ and not between the doses of gibberellic acid within the two levels of the Epi and Mesocarp factor.

Table 2. Effect of the presence and absence of part of the pericarp and the gibberellic acid upon the seed germination of Peumus boldus. Values correspond to mean values \pm standard error.

\begin{tabular}{ccccc}
\hline Treatments & $\begin{array}{c}\text { Germinative } \\
\text { capacity (\%) }\end{array}$ & $\begin{array}{c}\text { Maximum value of } \\
\text { Czabator }\end{array}$ & $\begin{array}{c}\text { Germinative } \\
\text { energy (\%) }\end{array}$ & $\begin{array}{c}\text { Period of } \\
\text { germination } \\
\text { (days) }\end{array}$ \\
\hline \multicolumn{2}{l}{ Epicarp and Mesocarp (A): } & & \\
With A & $19.1 \pm 2.6 \mathrm{a}$ & $0.0946 \pm 0.0120 \mathrm{a}$ & $19.1 \pm 2.8$ & $199 \pm 6$ \\
Without A & $51.4 \pm 3.1 \mathrm{~b}$ & $0.2304 \pm 0.0173 \mathrm{~b}$ & $48.8 \pm 3.2$ & $197 \pm 5$ \\
Gibberellic acid: & & & & \\
$0 \mathrm{~g} \mathrm{~L}^{-1}$ & $35.0 \pm 7.6 \mathrm{a}$ & $0.1560 \pm 0.0310 \mathrm{a}$ & $32.3 \pm 7.4$ & $201 \pm 5$ \\
$5 \mathrm{~g} \mathrm{~L}^{-1}$ & $37.7 \pm 6.8 \mathrm{a}$ & $0.1715 \pm 0.0293 \mathrm{a}$ & $36.5 \pm 5.1$ & $195 \pm 8$ \\
$10 \mathrm{~g} \mathrm{~L}^{-1}$ & $34.3 \pm 9.6 \mathrm{a}$ & $0.1600 \pm 0.0494 \mathrm{a}$ & $32.7 \pm 9.2$ & $197 \pm 7$ \\
\hline
\end{tabular}

Mean values with the same letter along a column for each factor are not significantly different. On the contrary different letters are significantly different at $\mathrm{P}$ value $<0.05$. 
the seeds since both gibberellins and abscisic acid have a profound influence on seed germination and dormancy (Bewley et al., 2013).

In this study, the experiments were done with seeds collected in December, and the seeds reached a germination rate of $51.4 \%$. In this respect, Botti and Cabello (1990) suggest that the time of the collection of fruits is important for germination, discussing that the collection of completely mature fruits (i.e., February) and subsequent sowing in autumn or winter, might be related to delayed germination. The difference between the results of the present study in contrast with the ones reported by Botti and Cabello (1990) might suggest that during the maturation months of the fruits (December to February), the amounts of germination inhibitors are incremented and that might explain a deeper dormancy, hence lower germination afterward. Abscisic acid accumulation, which is the most important natural inhibitor of germination, is related to the process of maturation (Hartmann \& Kester, 1999). In fleshy fruits, those inhibitors are present and the effects of inhibitors might be related to a high sugar concentration (Hartmann \& Kester, 1999).
Considering all treatments, the germination started after 152 days, and at day 201, no more seeds germinated (Table 2). This result is different from the one presented by Cabello and Donoso (2013), in which the germination began after 105 days, reaching a $44 \%$ germination rate. The velocity of germination here is slow, and both germination capacity and germinative energy have similar values. Regardless, after seven months, it was possible to have a higher percentage of seedlings, and in consequence, suitable plantlets to be used for restoration programs. In this respect, future experiments that consider also the use of beneficial microorganisms in the plantlets of $P$. boldus should be addressed. For instance, mycorrhizal fungi have proven to increase success in restoration programs (Neuenkamp et al., 2019) and recently it has been demonstrated that arbuscular mycorrhizal fungi are strongly related with $P$. boldus plants (Benedetti et al., 2018; Silva-Flores et al., 2019).

The main conclusions are as follows. To obtain high germination of $P$. boldus seeds, they should be collected in December, and the epicarp and mesocarp should be removed before sowing.

\section{Resumen}

R. Santelices-Moya, A. Cabrera-Ariza, F. Ávila-Rojas, y P. Silva-Flores. 2020. La remoción del epi y el mesocarpio del fruto semi-maduro de Peumus boldus y no el uso de ácido giberélico promueve la mayor germinación. Int. J. Agric. Nat. Resour. 145-151. Como consecuencia del cambio climático global los incendios forestales están aumentando en los ecosistemas mediterráneos. En este contexto, es necesario contar con herramientas eficientes para la rehabilitación o restauración de estos sistemas, siendo uno de las principales la efectiva propagación de plantas. Para esto, es necesario saber cómo factores relevantes afectan la variable germinación de las semillas en una planta de interés. Peumus boldus es una especie dominante de la zona Mediterránea de Chile y que ha sido fuertemente afectada por los incendios, por lo tanto, en la presente investigación se estudió el efecto conjunto de tratamientos pregerminativos, tales como remoción del epi- y mesocarpio y el uso de ácido giberélico en la germinación de frutos casí maduros de $P$. boldus colectados en el mes de diciembre. Los resultados muestran que solo la eliminación de epicarpio y mesocarpio afecta significativamente la germinación de las semillas, alcanzando una proporción de $51.4 \%$, la más alta reportada actualmente para esta especie en un estudio con experimento controlado. Estos resultados permiten sugerir que para obtener una mayor proporción de plántulas de $P$. boldus para programas de rehabilitación, 
las semillas deben ser colectadas en diciembre y sometidas al tratamiento pregerminativo de remover la cubierta carnosa, específicamente el epicarpio y mesocarpio, sin necesidad de usar ácido giberélico en concentraciones menores o iguales a $10 \mathrm{~g} \mathrm{~L}^{-1}$.

Palabras clave: AIB, boldo, endocarpio, mesocarpio, pericarpio, tratamiento pre-germinativo

\section{References}

Baskin, C.C., \& Baskin, J.M. (2014). Seeds: Ecology, Biogeography, and Evolution of Dormancy and Germination. $2^{\text {nd }}$ ed. San Diego: Academic Press.

Benedetti, S., Balocchi, F., \& Hormazábal, M. (2018). Hongos micorrícicos arbusculares (HMA) asociados a poblaciones naturales de Peumus boldus en Chile Central. Gayana Botánica, 75(1):431-437. http://dx.doi.org/10.4067/ S0717-66432018000100431

Bewley, J.D., Bradford, K.J., Hilhorst, H.W.M, \& Nonogaki, H. (2013). Seeds-Physiology of Development, Germination and Dormancy. New York: Springer.

Botti, C., \& Cabello, A. (1990). Anatomía y desarrollo de flores, frutos y semillas de boldo (Peumus boldus Mol.). Ciencia e Investigación Forestal, 4(1): 49-60.

Cabello, A., \& Donoso, C. (2013). Peumus boldus (Molina) Johnston, Boldo, Folo, Familia: Monimiaceae. In Donoso C. ed. Las Especies Arbóreas de los Bosques Templados de Chile y Argentina: Autoecología. Valdivia: Marisa Cuneo Ediciones. 510-515 p.

Czabator, F.J. (1962). Germination value: an index combining speed and completeness of pine seed germination. Forest Science, 8(4):386-396. https://doi.org/10.1093/forestscience/8.4.386

de la Barrera, F., Barraza, F., Favier, P., Ruiz, V., \& Quense, J. (2018). Megafires in Chile 2017: Monitoring multiscale environmental impacts of burned ecosystems. Science of the Total Environment 637-638:1526-1536. https://doi. org/10.1016/j.scitotenv.2018.05.119.

Donoso, C., \& Cabello, A. (1978). Antecedentes fenológicos y de germinación de especies leñosas chilenas. Ciencias Forestales 1:31-41.

Donoso, S., Peña-Rojas, K., Durán, S., Pacheco, C.,
Galdames, E., \& Espinoza, C. (2015). Influencia del raleo en el crecimiento, la condición hídrica y la respuesta fotosintética de Peumus boldus: pautas para la definición de su manejo silvicultural. Bosque (Valdivia) 36(3):457-466. http://dx.doi. org/10.4067/S0717-92002015000300012

Fatoretto, M.B., Moral, R. de A., Demétrio, C.G.B., Silva de Pádua, C., Menarin, V., Rojas, V.M.A., D'Alessandro, C.P., \& Delalibera Jr, I. (2018). Overdispersed fungus germination data: statistical analysis using R. Biocontrol Science and Technology 28(11):1034-1053. http://dx.doi.org /10.1080/09583157.2018.1504888

Figueroa, J., Armesto, J., \& Hernández, J. (1996). Estrategias de germinación y latencia de semillas en especies del bosque templado de Chiloé, Chile. Revista chilena de historia natural 69:243-251.

Gajardo, R. (1994). La Vegetación Natural de Chile. Clasificación y Distribución Geográfica. Santiago: Editorial Universitaria. 165 p.

García, E., \& González, M. (2018). Capítulo 5: Producción de plantas y propagación del Boldo. In: Benedetti, S. y Barros, S. (Eds.) Boldo (Peumus boldus Mol.). Avances en la Investigación para el Desarrollo de Modelos Productivos Sustentables. Santiago: Instituto Forestal. 143 p.

Hartmann, H.T., \& Kester, D.E. (1999). Propagación de Plantas, Principios y Prácticas. México: Editorial Continental, $757 \mathrm{p}$.

Homann, C. (1969). Nuevos aspectos acerca de la germinación de Peumus boldus. Boletín Universidad de Chile 78-79:25-30.

Lhermitte, S., Verbesselt, J., Verstraeten, W.W., Veraverbeke, S., \& Coppin, P. (2011). Assessing intra-annual vegetation regrowth after fire using the pixel based regeneration index. ISPRS Journal of Photogrammetry and Remote Sensing 66(1):17-27. https://doi.org/10.1016/j.isprsjprs.2010.08.004 
Luebert, F., \& Pliscoff, P. (2006). Sinopsis bioclimática y vegetacional de Chile. Santiago: Editorial Universitaria. $316 \mathrm{p}$.

Neuenkamp, L., Prober, S.M., Price, J.N., Zobel, M., \& Standish, R.J. (2019). Benefits of mycorrhizal inoculation to ecological restoration depend on plant functional type, restoration context and time. Fungal Ecology 40:140-149. https://doi. org/10.1016/j.funeco.2018.05.004

R Core Team. (2019). R: A language and environment for statistical computing. http://www.Rproject.org/.

Rodríguez, R., Matthei, O., \& Quezada, M. (1983). Flora arbórea de Chile. Concepción: Editorial Universidad de Concepción, 408 p.

Silva-Flores, P., Bueno, C.G., Neira, J., \& Palfner, G. (2019) Factors Affecting Arbuscular Mycorrhizal Fungi Spore Density in the Chilean Mediterranean-Type Ecosystem. Journal of Soil Science and Plant Nutrition 19:42-50. https://doi. org/10.1007/s42729-018-0004-6

Úbeda, X., \& Sarricolea, P. (2016). Wildfires in Chile: A review. Global and Planetary Change
146:152-161. https://doi.org/10.1016/j.gloplacha.2016.10.004.

Valencia, D., Saavedra, J., Brull, J., \& Santelices, R. (2018). Severidad del daño causado por los incendios forestales en los bosques remanentes de Nothofagus alessandrii Espinosa en la región del Maule de Chile. Gayana botánica 75(1):531-534. http://dx.doi.org/10.4067/ S0717-66432018000100531

Vallejo, R., Cortina, J., Vilagrosa, A., Seva, J.P., \& Alloza, J.A. (2003). Problemas y perspectivas de la utilización de leñosas autóctonas en la restauración forestal. In Rey-Benayas J.M, T Espigares-Pinilla, JM Nicolau-Ibarra eds. Restauración de Ecosistemas Mediterráneos. Alcalá de Henares: Universidad de Alcalá, 11-42 p.

Vogel, H., Razmilic, I., San Martín, J., Doll, U., \& González, B. (2005). Plantas medicinales chilenas. Experiencias de domesticación y cultivo de Boldo, Matico, Bailahuén, Canelo, Peumo y Maqui. Talca: Universidad de Talca. 194 p.

Wickham, H. (2016). ggplot2: Elegant Graphics for Data Analysis. New York: Springer-Verlag. 253 p. 